\title{
Fabrication of End Quenched Machine: Hardenability Evaluation
}

\author{
A. A. Yekinni' ${ }^{1}$ J. O. Agunsoye' ${ }^{2}$, S. A. Bello², I. O. Awe' ${ }^{3}$, S. I. Talabi ${ }^{4}$ \\ ${ }^{1}$ Department of Mechanical Engineering, Lagos State Polytechnic, Lagos, Nigeria \\ ${ }^{2}$ Department of Metallurgical and Materials Engineering, University of Lagos, Lagos, Nigeria \\ ${ }^{3}$ Department of Metallurgical Engineering, Yaba College of Technology, Lagos, Nigeria \\ ${ }^{4}$ Department of Metallurgical and Materials Engineering, University of Ilorin, Ilorin, Nigeria \\ Email: kunleyk2003@yahoo.com, jagunsoye@unilag.edu.ng, adekunle_b@yahoo.com, isaacton@yahoo.com
}

Received 28 November 2013; revised 29 December 2013; accepted 10 January 2014

Copyright (C) 2014 by authors and Scientific Research Publishing Inc.

This work is licensed under the Creative Commons Attribution International License (CC BY).

http://creativecommons.org/licenses/by/4.0/

(c) (i) Open Access

\section{Abstract}

The Jominy end quench machine was designed, manufactured and tested. The manganese steel was developed. The as-cast manganese steels were quenched in water at different austenising temperatures and hardenability test was carried out on the samples cut at different distances from the quenched surface with the use of the manufactured Jominy end quench machine. The optical microscope was used to investigate the microstructure of the cut samples. Results revealed that the Jominy end quench machine worked effectively with short cycle time and improved water management system. The extremely rapid cooling prevents the decomposition of the chromium carbides. However, the hardness values of the samples decreased with increase in the distance from the quenched surface and the size of the chromium carbides increased with austentic temperatures which is responsible for reduction in the hardness values of the quenched samples at higher austentinic temperature. The manufactured Jominy end quench machine has advantages of improved water management system and short processing time over the existing ones.

\section{Keywords}

Hardenability; Jominy Specimen; Martensitic; Mass Effect; Microstructure

\section{Introduction}

To select steel for a component that will be heat treated, it is important to know its hardenability. Hardenability refers to the property of steel which determines the depth of the hardness zone induced by quenching from the austenitizing temperature [1]. It is necessary to be knowledgeable about the hardenability of steel because it aids 
the selection of appropriate alloy-steel combinations. It also helps to minimise thermal stresses and distortion induced during and after the heat treatment processes for manufactured components. It is also sensitive to section sizes [2]. There are various scientific methods to measure hardenability of steel such as Grossman critical diameter method, Jominy end quench test, estimation of hardenability from chemical composition and fracture test among others [3]. The choice of Jominy end quench test is unique for a scientific point of view, i.e. it is reproducible, simple and highly functional. Various works have been carried out by researchers in the recent time to determine the hardenability of steel, alloy steel in particulars. [3] used a numerical algorithm to simulate the Jominy end quench test through continuous cooling diagram. [4] used computer aided design to interpret Jominy end quench test by comparing the hardenability of two bianitic steels with different compositions using finite element simulations.

Furthermore, [5] used Jominy end equipment to study the sensitivity of non-ferrous aluminium alloy (Al 7050).

In practical terms, most component parts for heat treatment are mostly non-symmetrical. Hence, there are distortions associated with the temperature gradient set up due to differences in the thickness. The temperature gradient varies with time, being less steep at later times. Thus the temperature of the centre lags in time behind the temperature of the surface. This means that cooling rate varies as a function of depth. The greater the depth, the slower the cooling rate. Different cooling rates can lead to different hardness in the centre than at edge. The edge could transform to martensite and centre to pearlite.

It is desirable to produce heat-treated quenched samples to a desirable hardness and homogenous structure across the section thicknesses, particularly for non-symmetrical casting. To avoid variable properties across section thickness, quenching must be rapid enough to prevent the nose of the cooling curve after the material is maintained at a constant temperature within martensite start $\left(\mathrm{M}_{\mathrm{s}}\right)$ and martensite finish $\left(\mathrm{M}_{\mathrm{f}}\right)$ range. However, this may not be the case for thick sections because the interior cools more slowly than the surface. But if one could modify this steel such that critical cooling rate is lower than thick pieces, it can be hardened throughout and even thicker pieces can be hardened to a considerable depth. This is of great practical importance in terms of our ability to produce a fully hardened part (which will also be fully brittle), and because subsequent tempering will be successful in producing the desired strength and ductility throughout the part. In addition, one could use less severe quenches to avoid problems with warping and cracking.

To begin a design work without determining the hardness, toughness, strength or other technical details of the metal piece will make a work blindly or rather as a nonprofessional [6]-[9]. The existing Jominy end quench equipment is characterised with poor water disposal, poor time management in the processing cycle and cumbersomeness. However, in this work, the Jominy end quench machine was designed, manufactured and tested for manganese steel bars. The fabricated machine is aimed at improving the water disposal system associated with James Marrow's machine designed in 2001, the processing cycle time per sample and machine mobility.

\section{Materials and Methods}

\subsection{Material Selection}

In other to prevent corrosion, 18/8 grade stainless steel was used to construct the boiler tank, water returning tank and Quenching tank. PVC pipes were used to convey water from the pump into various units to reduce cost. To enable better water control, thermoset valves were inserted in the pipes at various sections. A support base was constructed to hold the quenching tank in a proper position. Necessary assumptions were made on selection of type and power rating of water pump and electric heater. The various components of the machines and the materials used in their fabrications are presented in Table 1.

\subsection{Methods}

\subsubsection{Theoretical Frames}

\section{Design of Tanks}

Boiler tank, Quenching tank and Returning tank are all made of $1 \mathrm{~mm}$ thick stainless steel sheet.

Volume of each tank was determined using Equation (1).

$$
V=\frac{\pi}{4} D^{2} H
$$


Table 1. Material selection for machine parts.

\begin{tabular}{ccc}
\hline S/N & Machine parts & Materials \\
\hline 1 & Base frame & Mild steel \\
2 & Boiler tank & Stainless steel \\
3 & Control valve & Thermoset \\
4 & Water returning pipes & Polyvinyl chloride \\
5 & Returning tank & Stainless steel \\
6 & Specimen frame & Mild steel \\
7 & Specimen & Manganese steel \\
8 & Quenching tank & Stainless steel \\
9 & Nozzle & Stainless steel \\
10 & Support frames & Mild steel \\
11 & Control panel & Stainless steel \\
\hline
\end{tabular}

where, $V=$ Volume of tank, $D=$ Diameter of tank, $H=$ Height of tank.

\subsubsection{Fundamental Assumptions}

\section{1) Water pump selection}

A one horse power capacity water pump was selected to supply enough pressure to suck water from the reservoir to the boiler tank and deliver to the nozzle. The theoretical pump power in Kw was determined using the Equation (2)

$$
P_{h}=q \rho g h
$$

where, $P_{h}=$ Theoretical power of pump (KW), $q=$ Flow capacity $\left(\mathrm{m}^{3} / \mathrm{h}\right), \quad \rho=$ Density of fluid $\left(\mathrm{Kg} / \mathrm{m}^{3}\right), g=$ Gravity $\left(9.81 \mathrm{~m} / \mathrm{s}^{2}\right), h=$ Differential head $(\mathrm{m})$.

From Equation (3), the power of the pump shaft was also determined.

$$
P_{s}=P_{h} / \eta
$$

where, $P_{s}=$ Shaft pump power (KW), $\eta=$ Pump efficiency.

\section{2) Electric heater selection}

An $800 \mathrm{~W}$ electric heater was selected. The power output is sufficient enough to heat the quenching water to the required quenching temperature within a short period. The heater was inserted through the opening created at the lower base of the boiler tank which was controlled by a thermostat.

\section{3) Nozzle design}

The nozzle of diameter $10 \mathrm{~mm}$ inside the quenching tank was made of stainless steel located $450 \mathrm{~mm}$ away from the base of the specimen. Discharge flow distance can be varied with a control valve to accommodate different lengths of specimen.

\subsection{Mode of Operation of the Machine}

All valves were closed before the operation, after which the boiling tank was filled with water; the furnace was preheated to the different temperatures set for soaking the Jominy specimen depending on their material composition. The Jominy specimen was placed in the furnace and soak for one hour per $25.44 \mathrm{~mm}$ thickness; the heater was turned on and set to appropriate temperature. Before putting on the pump, the two control valves and the valve connecting the quenching tank with the returning tank were opened. This enables water to flow from the quenching tank to the boiler tank via the returning tank. The Jominy specimen was removed from the furnace and placed on the specimen frame. Then, the water pump was switched on and the water flow distance to quench the specimen to room temperature (about 15 minutes) was regulated with the aids of upper control valves. The water pump was switched off after the specimen was cooled to room temperature. The specimen was removed and the samples were cut at different distance from the quenched surface. 


\subsection{Experimental Procedure}

A manganese steel in as-cast condition is relatively brittle and possess low impact energy. However, when it is solution treated within the austenitic range and oil quenched, its mechanical properties are improved. Its ability to absorb repeated impact load without excessive work hardened has made manganese steel a suitable material in quarrying application especially in making parts for crushing and grinding hard solid mineral. In testing the performance of the manufactured Jominy end quench machine, the manganese steel of dimensions $20 \times 20 \times$ $150 \mathrm{~mm}$ was produced. Sample representatives of the manganese steel were taken from one of the batch melt of manganese steels of ASTM 128C equivalent. The melt was poured into a silica sand mould at $1500^{\circ} \mathrm{C}$. The composition analysis of steel scrap, the foundry return and the manganese steel were carried out. The bars were machined to standard Jominy samples for hardenability test. The manganese steel Jominy samples were subjected to inter-critical annealing and homogenisation treatment at $800^{\circ} \mathrm{C}, 900^{\circ} \mathrm{C}, 1000^{\circ} \mathrm{C}, 1100^{\circ} \mathrm{C}$ respectively; held at the temperatures for 47 minutes $(25 \mathrm{~mm} /$ hour $)+2.5$ minutes to compensate for edge effect and quenched in water to room temperature. For the determination of hardness values and microstructural investigations, samples were cut at the quenched surface, $40 \mathrm{~mm}$ and $80 \mathrm{~mm}$ from the quenched surface respectively. Sample surfaces for microstructural examination were prepared using polishing machine model Tegraphol-31, with silicon dioxide emery paper of grit size $4 \times 10^{-2} \mu \mathrm{m}$ and polished allegro diamond grit paper was also used. $100 \mathrm{~mL}$ ethanol and $3 \mathrm{~mL}$ nitric acid were used as etchants.

\section{Results and Discussion}

\subsection{Jominy End Quench Machine}

Figures 1-3 show the third angle projection, the geometric model and picture of the manufactured Jominy end quench machine.

\subsection{Microstructural Examination}

Figures 4 and 5 show the optical micrographs of the quenched Jominy samples of manganese steels held at

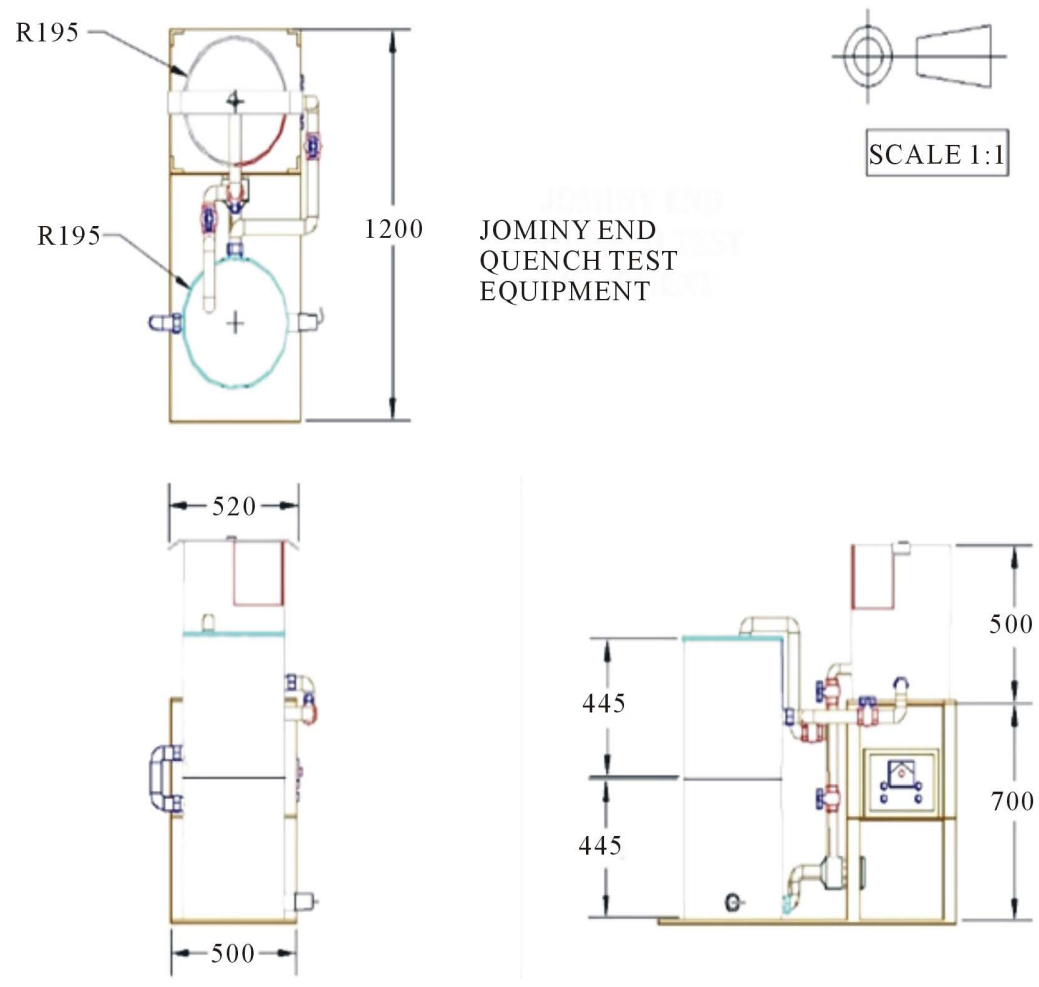

Figure 1. Third angle projection of the Jominy end quench machine. 


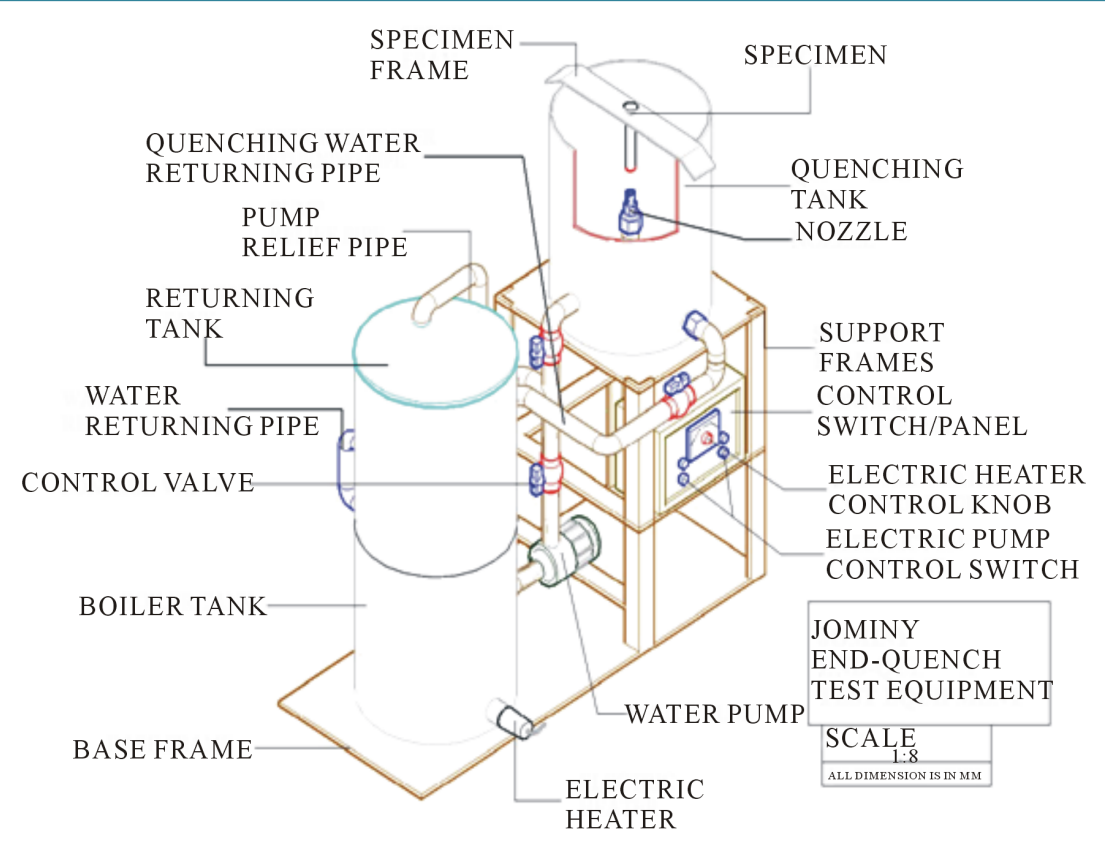

Figure 2. The geometric model of the Jominy end quench machine.

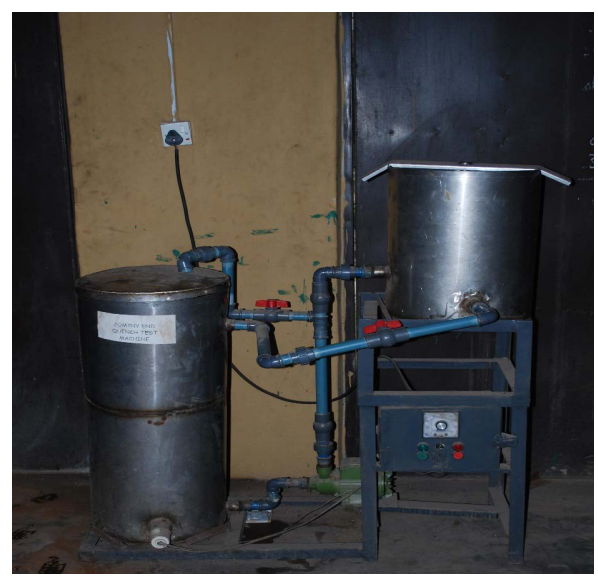

Figure 3. The fabricated Jominy end quench machine.

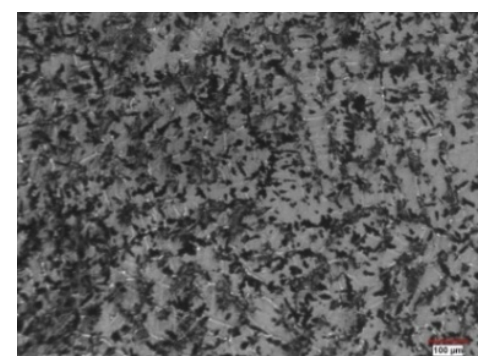

(a)

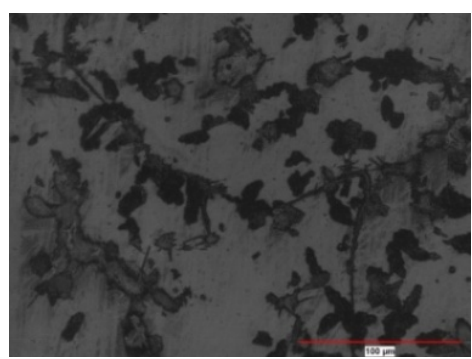

(b)

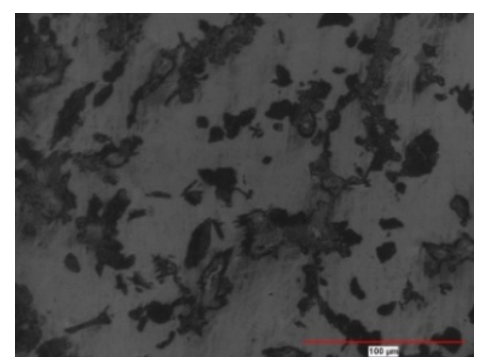

(c)

Figure 4. (a) Micrographs of manganese steel at $800^{\circ} \mathrm{C}$ : quenched Jominy sample surface; (b) Micrographs of manganese steel at $800^{\circ} \mathrm{C}: 40 \mathrm{~mm}$ from quenched end; (c) Micrographs of manganese steel at $800^{\circ} \mathrm{C}: 80 \mathrm{~mm}$ from quenched end.

$800^{\circ} \mathrm{C}$ and $1100^{\circ} \mathrm{C}$ respectively. The microstructures revealed that there are presences of the chromium carbide in the martensite matrix. However, the proportion of the chromium carbide decreased as the distance from the 


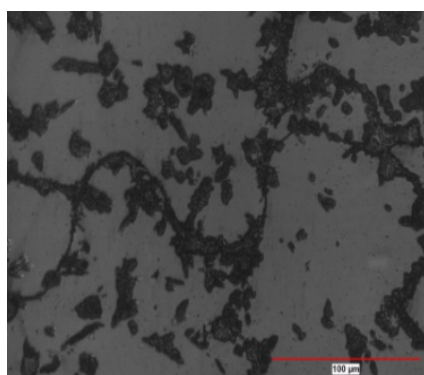

(a)

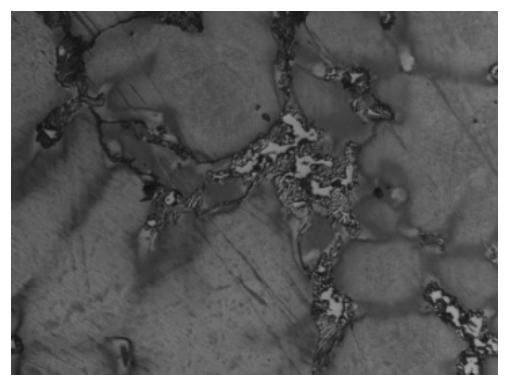

(b)

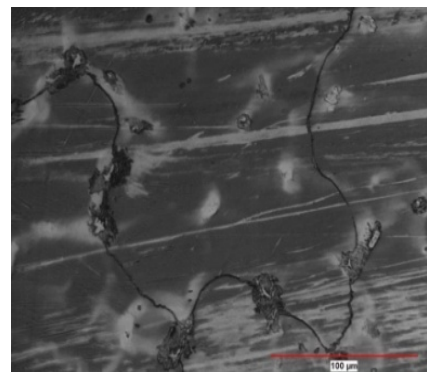

(c)

Figure 5. (a) Micrographs of manganese steel at $1100^{\circ} \mathrm{C}$ : quenched Jominy sample surface; (b) Micrographs of manganese steel at $1100^{\circ} \mathrm{C}: 40 \mathrm{~mm}$ from quenched end; (c) Micrographs of manganese steel at $1100^{\circ} \mathrm{C}: 80$ $\mathrm{mm}$ from quenched end.

quenched surface increased. The increase in the chromium carbide contents towards the quenched surface might be due to higher cooling rate which prevents the decomposition of the chromium carbides. Furthermore, the structure of the chromium carbides in Figure 4 is finer than that in Figure 5. This may be attributed to grain growth at the higher heating temperature.

\subsection{Hardenability}

Figure 6 shows the relationship between hardness values and distance from the water quenched surface. It was discovered that the hardness values of the sample quenched at $1100^{\circ} \mathrm{C}$ were lower than that of the sample quenched at $800^{\circ} \mathrm{C}$. The decrease in hardness may be attributed to coarse chromium carbides of the sample quenched at $1100^{\circ} \mathrm{C}$ (see Figures 4, 5). Furthermore, the hardness values decreased as the distance from the quenched surface increased. This is due to lower chromium carbide contents in the matrix.

\subsection{Spectrometric Analysis}

The elemental compositions of the steel scrap, foundry return and the developed manganese steel are shown in Tables 2-4 respectively.

\section{Conclusions}

From the results and discussion, the following conclusions can be drawn:

1) The manufactured Jominy end quench machine worked effectively with short cycle time.

2) The hardness of the quenched sample is not uniform throughout the entire volume of the sample. Hence, the hardness decreases with the distance from the quenched surface.

3) The morphology of the microstructure varies with the distance from the quenched surface. Hence, the ex-

Table 2. Elemental composition of the steel scrap.

\begin{tabular}{cccccccc}
\hline Elements & $\mathrm{C}$ & $\mathrm{Si}$ & $\mathrm{Mn}$ & $\mathrm{P}$ & $\mathrm{S}$ & $\mathrm{Al}$ & $\mathrm{Fe}$ \\
\hline \% Spec & 0.350 & 0.250 & 0.500 & 0.001 & 0.001 & 0.020 & 98.878 \\
\hline
\end{tabular}

Table 3. Elemental composition of the foundry return.

\begin{tabular}{ccccccc}
\hline Elements & $\mathrm{Si}$ & $\mathrm{Mn}$ & $\mathrm{Cr}$ & $\mathrm{P}$ & $\mathrm{S}$ & \\
\hline \% Spec & 1.250 & 12.60 & 2.200 & 0.001 & 0.001 & 83.948 \\
\hline
\end{tabular}

Table 4. Elemental composition of the produced manganese steel.

\begin{tabular}{ccccccccc}
\hline Elements & C & Si & Mn & Cr & P & S \\
\hline \%Spec & 1.100 & 0.650 & 14.000 & 1.800 & 0.050 & 0.052 & 82.348 \\
\hline
\end{tabular}




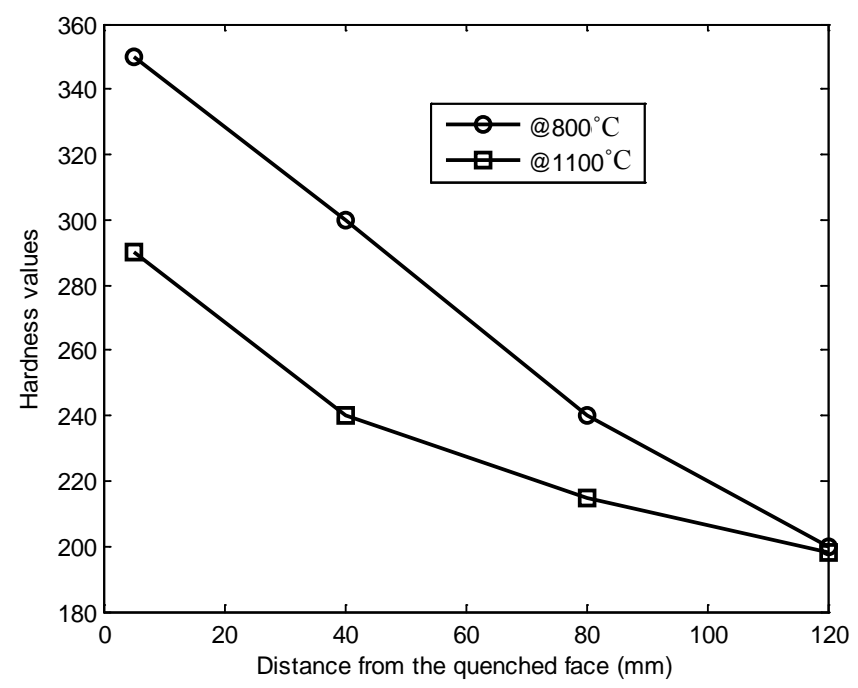

Figure 6. Hardness values with distance from the quenched surface.

treme rapid cooling/quenching avoids the grain growth.

4) As a result of shorter processing time, when compared the operation of the manufactured Jominy end quench machine with the existing one, the amount of water used for quenching process is reduced to the minimum. Hence water disposal system of the machine is enhanced.

\section{Acknowledgements}

Authors wish to appreciate the HOD of the mechanical department of Lagos State Polytechnic, Ikorodu, Lagos, for his permission to carry out the fabrication at the Mechanical Engineering workshop. Also, the appreciation is due to the H.O.D of Metallurgical and Materials Engineering for his permission to carry some tests in the Metallurgical and Materials workshop.

\section{References}

[1] Prabhudav, K.A. (1988) Handbook of Heat Treatment of Steels. Tata McGraw-Hill Publishing Company Limited, New Delhi.

[2] Marrow, J. (2001) Understanding the Jominy End Quench Test. Manchester Materials Science Centre UMIST, Manchester.

[3] Kadpal, B.C., et al. (2001) A Review of Jominy Test and Determination of Effect of Alloying Elements on Hardenability of Steel Using Jominy End Quench Test. International Journal of Advances in Engineering and Technology, 1, 65-71.

[4] Pietrzyk, M. and Kuziak, R. (2011) Computer Aided Interpretation of Results of the Jominy Test. Archives of Civil and Mechanical Engineering, 11, 707. http://dx.doi.org/10.1016/S1644-9665(12)60111-3

[5] Kutz, M. (2002) Handbook of Materials Selection. John Wilson \& Sons Inc., New York. http://dx.doi.org/10.1002/9780470172551

[6] Orivjir, J.A. (2012) Design and Manufacturing Plan of a Jominy Testing Device. Bachelor’s Thesis, HAMK University of Applied Science, Mechanical Engineering and Production Technology, Riihimaki.

[7] Bain, E.C. and Paxton, H.W. (1966) Alloying Elements in Steel. American Society for Metals, Cleveland.

[8] Papworth, A. and Williams, D.B. (2000) Segregation to Prior Austenitic Grain Boundaries in Low Alloy Steels. Scripta Materialia, 42, 1107-1112. http://dx.doi.org/10.1016/S1359-6462(00)00335-3

[9] Research Institute of Industrial Science and Technology (RIST) (1988) Model for Controlling and Predicting the Quality in C-Mn Steels. Technical Report. 